\title{
THE OCTOBER 1979 REGIME OF MONETARY CONTROL AND THE BEHAVIOR OF THE MONEY SUPPLY IN 1980*
}

\author{
Robert L. Hetzel
}

\section{Introduction}

In October 1979, the Federal Reserve System instituted a regime of monetary control characterized by lagged-reserve accounting and a nonborrowedreserves operating target. Section JI of this article provides an analytical framework for this regime. Section III appraises the efficacy, for purposes of monetary control, of this regime by comparing it to a regime characterized by contemporaneous-reserve accounting and a total-reserves operating target. Section IV describes the actual implementation of the regime. Section $\mathrm{V}$ examines the question of why the rate of growth of the money supply was so variable within 1980.

\section{An Analytical Framework}

This analysis concentrates on the determination of the level of nominal bank deposits. The microeconomic analysis begins with the markets for bank reserves and for bank credit. Banks are middlemen and these two markets, respectively, summarize for them the cost of borrowing and the return to lending. More specifically, in a competitive banking system with a systemwide market for bank reserves, the price of reserves in the reserves market constrains the asset acquisition (credit extension) of individual banks. A bank purchases an asset by crediting, either directly or via a correspondent bank, the deposit account of the seller of the asset. The cost of purchasing an asset is then the cost of replacing the

* Reprinted with permission from the Journal of Money, Credit, and Banking, vol. 14 (May 1982), pp. 234-51. Copyright (C) 1982 by the Ohio State University Press. Footnotes 5 and 12 have been added to the present version.

The author acknowledges useful criticism from Neil G. Berkman, Marvin S. Goodfriend, Robert E. Keleher, Robert D: Laurent, Raymond E. Lombra, Bennett T. McCallum, Thomas Mayer, Frank E. Norton, William Poole, Peter A. Tinsley, Roy H. Webb, and two anonymous referees. Ken Anderson and Duane Musser did the graphics. reserves lost when the seller of the asset draws down his account. When the interest rates in the reserves and credit markets differ, banks respond by adjusting their holdings of interest-bearing assets. The process of arbitraging the interest rates in these two markets determines the nominal quantity of interest-bearing assets (credit extension) of the banking system and, as a consequence, its deposits.

Banks possess many ways of acquiring reserves. For example, they can use the Eurodollar, certificate of deposit, repurchase agreement, or Federal funds market. Banks arbitrage the rates across these markets so that the price of obtaining reserves from each source is equal, apart from considerations of term structure, risk, and transactions costs. It is, therefore, convenient to represent the price of reserves by a single price, the funds rate. The Federal Reserve influences the cost of asset acquisition to banks through its influence on the Federal funds rate. By altering the funds rate, the Federal Reserve can move the banking system along the demand for credit schedule it faces, thereby determining the nominal quantity of bank credit outstanding and, consequently, the nominal quantity of total bank deposits.

The way in which the Federal Reserve influences the funds rate is summarized by the shape of the reserve-supply schedule in the market for bank reserves. With a nonborrowed-reserves operating target, this schedule possesses a vertical section, at the existing value of nonborrowed reserves, for values of the funds rate less than the discount rate (Figure 1a). As banks collectively increase their use of the discount window, that is, as total reserves increase above the level of nonborrowed reserves, the Federal Reserve raises the nonpecuniary cost of borrowing. The marginal effective cost of obtaining reserves from the window rises above the discount rate and, through arbitrage, the funds rate also rises above the discount rate. The positive relationship between borrowed reserves and the differential between the funds rate 
Figure 1a

RESERVES MARKET

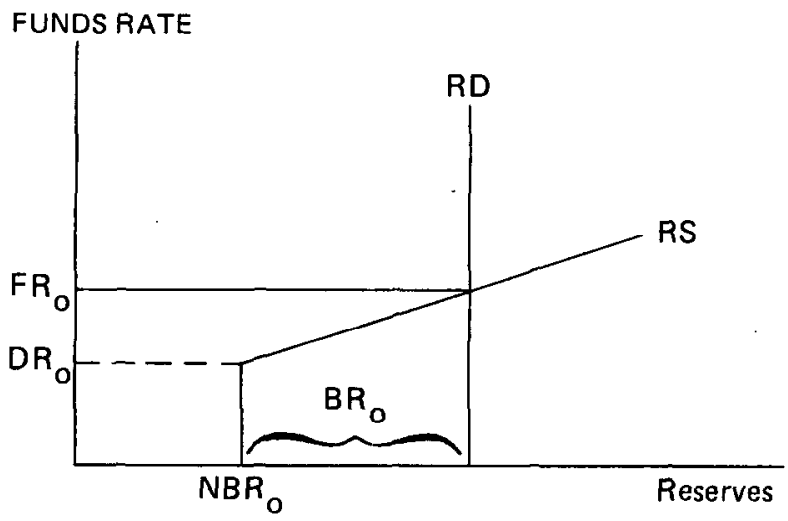

Figure 1b

\section{BANK CREDIT MARKET}

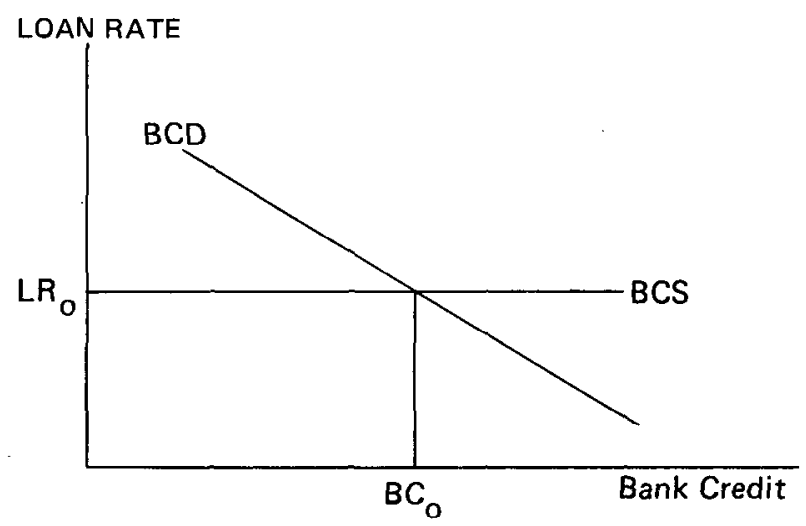

$F R$ is the funds rate; DR the discount rate; BR borrowing from the discount window; NBR nonborrowed reserves. RS is the reservesupply schedule of the Federal Reserve. RD is the reserve-demand schedule of the banking system. LR is the nominal interest rate on bank credit. BC is the stock of nominal bank credit. BCS and BCD are the bank-credif supply schedule and bank-credif demand schedule, respectively. The 0 's denote particular values.

and the discount rate is shown in Figure 1a by the positively sloping section of the reserve-supply schedule.

Because of lagged-reserve accounting, the reservedemand schedule is vertical. Required reserves are predetermined because they depend upon deposits held two weeks in the past, rather than upon deposits held in the current statement week. Also, desired excess reserves appear to be practically interestinsensitive in the October 1979 regime, at least at current levels of interest rates. For example, a regression of excess reserves on the funds rate and a lagged value of excess reserves from October 1979 through 1980 reveals the absence of a statistically significant relationship between excess reserves and the funds rate.

The demand schedule in the market for the stock of bank credit is downward sloping. The supply schedule is horizontal (Figure 1b). This characteristic derives from lagged-reserve accounting for the following reason. Changes in bank credit produce changes in deposits, but, because of lagged-reserve accounting, the associated changes in required reserves, and thus in the demand for reserves by the banking system, occur with a lag of two weeks. The banking system in the first instance accommodates changes in the demand for credit at the existing rate on bank loans because, initially, such accommodation does not affect its cost of funds, the funds rate. The supply schedule is drawn at the height of the funds rate plus a markup. This markup, which is quite variable, reflects the transactions costs of intermediation. It reflects term structure considerations in that the loan rate is for longer maturities than the funds rate. Finally, it reflects the fact that while the funds rate moves rapidly in line with other moneymarket rates, the loan rate (in particular, the prime rate) moves sluggishly. ${ }^{\mathrm{I}}$

The analytical apparatus summarized in Figure 1 can be illustrated by considering the effect of a reduction in nonborrowed reserves. Because the quantity of reserves demanded is fixed in a given reserveaccounting period, borrowing from the discount window rises by an amount equal in magnitude to the reduction in nonborrowed reserves. As a result, the marginal effective rate of interest on borrowed reserves rises. (In Figure 3a, RS shifts leftward to $\mathrm{RS}^{\prime}$ and intersects the unchanged $\mathrm{RD}$ schedule at a higher funds rate. The remainder of Figure 3 is inapplicable to this example.) The cost of asset acquisition to banks rises. The bank-credit supply schedule shifts upward and intersects the bank-credit demand

\footnotetext{
1 A fundamental issue is whether a theory of the money supply process should be organized primarily around the market for the quantity of money (New View) or primarily around the market for bank credit (Old View). The Appendix indicates how the market for the quantity of money can be incorporated into the model in the paper along either New or Old View lines. The discussion is reserved for an appendix because the method of incorporation of this market does not alter the analysis in the paper. (The discussion is simplified by the assumption that all bank deposits are checkable deposits.)
} 
schedule at a point corresponding to a smaller quantity of bank credit and deposits. ${ }^{2,3}$

An increase in the discount rate also lowers bank deposits. The increase produces the same increase in the height of the reserve supply schedule and, consequently, the same increase in the funds rate. (In Figure 3a, RS' shifts upward to $\mathrm{RS}^{\prime \prime}$ and intersects the unchanged $\mathrm{RD}$ schedule at a higher funds rate. The remainder of Figure 3 is inapplicable to this example.) An increase in the discount rate does not reduce the differential between the funds rate and the discount rate until after the passage of two weeks when the reserve demand schedule shifts leftward. (This implication of the model is supported by the data presented in [4, pp. 25-27].) $)^{4}$

In principle, in the October 1979 regime, the nonborrowed-reserves target would be derived as follows from the target for checkable deposits that is implied by the money supply target. Given the public's demand for the nonmonetary deposits of banks, the targeted value of checkable deposits will imply a particular level of bank credit, say, $\mathrm{BC}_{0}$ (see Figure 1). Given the position of the bank-credit demand schedule, this level of bank credit is associated with the rate on bank loans, $L_{0}$. This rate will imply a funds rate, $F R_{0}$, given an estimate of the markup of

2 With a two-week lag, this reduction in bank deposits causes a reduction in required reserves and the reservedemand schedule, RD, shifts leftward. The funds rate falls. This fall causes the banking system to increase its intercst-bcaring assets and, as a byproduct, its deposits. The original decrease in nonborrowed reserves produces a lower level of deposits, but the approach to the lower level is, as just suggested, an oscillatory one.

${ }^{3}$ Bank checkable deposits, the quantity relevant for determination of the money supply, equal total bank deposits minus the nonmonetary deposits of banks. The rate banks pay on their nonmonetary deposits equals the funds rate adjusted for the term-structure of interest rates (abstracting from $R$ eg. $Q$ ). The public compares the rate on bank nonmonetary deposits with moneymarket rates and decides how much of its liquid assets to allocate to the nonmonetary deposits of banks. The nominal quantity of bank checkable deposits is then determined as a residual, that is, by subtracting the nonmonetary deposits desired by the public from total bank deposits. The variability in the demand for the nonmonetary liabilities of banks causes considerable divergence in the behavior of bank credit and the money stock. As described in Section IV, the Federal Rescrve offscts the effect of this variability on the money supply by accommodating reserve demand due to banks' nonmonetary deposits.

4 The monetary consequences of the behavior of the discount rate depend upon the particular regime of monetary control. When the funds rate serves as the operating target, as in the pre-October 1979 regime, the behavior of the discount rate is largely irrelevant. Given the funds-rate target, changes in the discount ratc change the average, but not the marginal, cost of asset acquisition to banks and do not, therefore, affect the money supply (see $[6$, p. 29]). the loan rate over the rate banks pay on their liabilities. By producing a price of reserves equal to $F R_{0}$, the Fedcral Reserve will cause banks to alter their holdings of interest-bearing assets until the interest rate in the bank credit market is $L R_{0}$, bank credit is $\mathrm{BC}_{0}$, and the deposit target is achieved.

The Federal Reserve must choose its nonborrowedreserves target so as to shift the reserve supply schedule, RS, into a position such that its interaction with the reserve demand schedule, $\mathrm{RD}$, will produce the desired funds rate, $\mathrm{FR}_{0}$. For the first two weeks of a targeting interval, the position of the reserve demand schedule is given by the predetermined value of required reserves plus an estimate of desired excess reserves. Thereafter, assuming for analytical convenicnce prompt movement of the money supply to its targeted value, the position of the reserve demand schedule is derived by estimating the amount of required and excess reserves associated with the targeted value of the money supply.

This procedure could in principle allow the Federal Reserve to set a money-supply target for a future interval and then specify the values for nonborrowed reserves necessary to achieve this target (feedforward control of the money supply). It would require, however, an ability to predict shifts in the bank-credit demand schedule and an ability to understand the dynamics of the interaction between the reserves and bank-credit market. Perhaps because of the difficulty of fulfilling such requirements, the Federal Reserve has adopted a different, conceptually less-complicated targeting procedure (more properly characterized as a feedback control procedure). The actual procedure is described in Section IV.

\section{Efficacy of the October 1979 Regime}

The efficacy, for purposes of monetary control, of the October 1979 regime depends upon the predictability of the key behavioral relationships of this regime. It is instructive to contrast the October 1979 regime with a regime of contemporaneous-reserve accounting and a total-reserves operating target. By definition, bank deposits (D) equal the product of the reciprocal of the total reserves (TR) to deposits ratio of the banking system and total reserves.

$$
\mathrm{D}=\frac{1}{(\mathrm{TR} / \mathrm{D})} \mathrm{TR}
$$

In the latter regime, determination of the nominal quantity of bank deposits can be summarized by replacing, in the above definitional relationship, the actual total reserves-deposits ratio with the total 
reserves-deposits ratio desired by the banking system. The reason that the definitional relationship can be replaced by a behavioral relationship is that, given total reserves, the funds rate varies in order to bring the actual total reserves-deposits ratio into line with the banking system's desired total reserves-deposits ratio. For example, consider an increase in total reserves that leaves the actual in excess of the desired total reserves-deposits ratio. Banks collectively will try to sell Federal funds causing the funds rate to fall. The fall in the cost of asset acquisition spurs banks to acquire interest-bearing assets. These acquisitions increase bank deposits and the actual total reservesdeposits ratio falls. The process ends when the actual is reduced to the desired total reserves-deposits ratio. In sum, in a regime characterized by contemporaneous-reserve accounting and a total reserves operating target, a reserves-deposits, or a reservesmoney, multiplier relationship is a useful analytical device for understanding the money-supply process.

In contrast, in a regime of lagged-reserve accounting and a nonborrowed-reserves operating target, a reserves-money multiplier relationship is not an analytically (or operationally) significant concept. Note first that the total reserves-deposits ratio does not exist as a behavioral relationship. One way of making this point is to note the lack of a relationship between total reserves and deposits over a particular reserve accounting period. Recall the description in Section II of how a reduction in nonborrowed reserves lowers deposits. For the reserve-accounting period in which the reduction in nonborrowed reserves occurs, deposits fall without any change in required reserves and, consequently, without any significant change in total reserves. Despite the exogenously given value of total reserves, deposits change.

The practical impossibility of targeting total reserves directly in this regime reflects the lack of a behavioral relationship between total reserves and deposits. The reserve-demand schedule is approximately completely interest inelastic because of laggedreserve accounting. The reserve-supply schedule is by definition completely interest inelastic with a totalreserves operating target. An attempt to target total reserves, therefore, would produce, in a particular reserve-accounting period, a razor's edge situation in which a reserve surplus would force the funds rate down toward zero and a reserve deficiency would force the funds rate up to a point where banks would be willing to default on their deficiency. The funds rate cannot equilibrate the market for reserves if neither the reserve-demand nor the reserve-supply schedule possesses some interest elasticity. (A penalty discount rate, because it would render the supply of total reserves interest inelastic, is, likewise, not feasible in the Octuber 1979 regime.)

It is, as a formal matter, possible to write down a "money-multiplier" relationship for a regime of lagged-reserve accounting and a nonborrowedreserves operating target, that is, a formula equating money (or deposits) to the product of a "multiplier" and nonborrowed reserves. One of the ratios in this "multiplier," however, is the ratio of deposits in the statement week two weeks in the past to deposits in the current statement week. (This "moneymultiplier" formula is written out in $[2$, p. 53], although the net source base, high-powered money minus borrowed reserves, is used in place of nonborrowed reserves.) The ratio of lagged deposits to current deposits is not a behavioral relationship; therefore, this "multiplier" is not a useful summary of the behavioral relationships that determine bank deposits and the money supply. There is a functional relationship for the October 1979 regime relating deposits to nonborrowed reserves, but it depends upon the key behavioral relationships of the regimethe upward sloping section of the reserve-supply schedule, the markup of the loan rate over the funds rate, and the bank-credit demand schedule. The influence of thesc behavioral relationships is not use fully summarized within a money-multiplier framework.

The central idea of this section is that the efficacy of the October 1979 regime of monetary control, relative to a regime of contemporaneous-reserve accounting and a total-reserves operating target, depends upon the relative predictability of the key behavioral relationships of these regimes. The key behavioral relationships of the former regime are the reserve-supply schedule, the markup of the loan rate over the funds rate, and the bank-credit denand schedule. The key relationship in the latter is the total reserves-deposits ratio.

Evidence from the 1970 s indicates that the bankcredit demand schedule is not predictable. In the 1970 s, the Federal Reserve used the funds rate as its operating target. In a regime of funds rate targeting, the reserve-supply schedule and the bank-credit supply schedule are infinitely elastic (at values, respectively, equal to the funds rate and somewhat above the funds rate adjusted for the term structure of interest rates). Consequently, shifts in the bankcredit demand schedule determine simultaneously bank interest-bearing assets, deposits, and reserves. (Reserves appear with a two-week lag. Because of lagged-reserve accounting, deposits determine the 
quantity of reserves demanded two weeks in the future. The Federal Reserve automatically supplies this quantity as a consequence of targeting the funds rate.) In the 1970s, the Federal Reserve invested considerable amounts of staff effort in an attempt to predict the behavior of bank deposits and the money supply for its targeted funds rate. This effort was largely unsuccessful, apart from predicting seasonal movements left in the money supply by imperfect seasonal adjustment procedures. (This unsatisfactory situation was referred to in statements by the Federal Reserve that explained the change in monetary regime in October 1979. See [10, p. 139].) The difficulty of predicting the behavior of deposits and the money supply in a regime with a funds rate operating target is evidence that the bank-credit demand schedule is not predictable.

The markup of the loan rate over the funds rate is extremely variable. Even if it and the bank-credit demand schedule are unpredictable, however, predictability of the upward-sloping section of the reserve-supply schedule would make possible simple feedback control of the money supply. Whenever the money supply deviated from target, as a consequence of a fixed target for nonborrowed reserves, borrowed reserves and the funds rate would vary in a way that would offset the deviation. The target for nonborrowed reserves could also be changed. A review of experience under the new operating procedures by economists at the New York Trading Desk, however, indicates that the reserve supply schedule is not predictable. "The federal funds rate ... can vary widely for a given level of borrowing. Changes in the federal funds rate appear to be strongly influenced not only by the borrowing level itself but also by past borrowing experience and by market expectations of future rate developments" [8, pp. 28-29]. Of particular interest is the discussion of the "distinctive episodes in which the spread [between the funds rate and the discount rate] departed dramatically from the basic relationship" [8, pp. 29ff.].

How predictable would the total reserves-deposits ratio be in a regime of contemporaneous-reserve accounting and a total-reserves operating target? Unfortunately, this question cannot be resolved empirically on the basis of the past relationship between total reserves and deposits. In the pre-October 1979 regime, the Federal Reserve used the funds rate as its operating target (see [5]). As discussed above, with a funds-rate operating target, deposits and total reserves become simultaneously determined endogenous variables with bank credit the exogenous variable. If total reserves were to become an exogenously determined variable, the relationship between it and deposits would be expected to become less predictable. (This point is made in [7, p. 932]).

On the other hand, the potential does exist that the total reserves-deposits ratio would be a predictable relationship in a regime of the above type. In such a regime, assuming uniform reserve requirements applied only to monetary liabilities, unpredictability of the total reserves-deposits ratio would arise primarily from the behavior of excess reserves. Shifts in the bank-credit demand schedule could cause unpredictable changes in deposits via the effect on excess reserves. If, however, excess reserves are largely interest inelastic, the effect of these shifts would be neutralized. More generally, the financial incentive that hanks have to manage their holdings of excess reserves creates the potential that the excess reservesdeposits, and thus the total reserves-deposits, ratio would be predictable.

It is the demonstrated unpredictability of the basic behavioral relationships that shape the process of deposit determination in the October 1979 regime that renders appealing an experiment with a different regime of monetary control. In the October 1979 regime, in order to control the money supply with other than the crudest kind of feedback-control procedure, the Federal Reserve must determine the funds rate implied by its money-supply target-an impossible task because of the unpredictability of the bank-credit demand schedule. Furthermore, the funds rate must be set indirectly by operating through another unpredictable relationship, the reserve supply schedule. Because the central behavioral relationship of a regime of contemporaneous-reserve accounting and a total-reserves operating target is a potentially stable one, this regime offers the prospect of improved monetary control.

\section{Implementation of the October 1979 Operating Procedures}

At its meetings, the Federal Open Market Committee (FOMC) specifies an intrayearly target for the rate of growth of the money supply. From this target, the board staff derives a target for the average level of total reserves for either one or two targeting intervals between the current and succeeding FOMC meeting. This target is an intermediate target in that it is not directly under the control of the System Open Market Account Manager (the desk). The FOMC also specifies an initial target for borrowed reserves, again as an average to be achieved over the 
intermeeting interval. 5 The difference between the total-reserves and borrowed-reserves targets determines the intermeeting target for average nonborrowed reserves. This target is an operating target, and it is translated into a weekly path.

It is useful to recall the reserve identity

$$
\mathrm{NBR}-\mathrm{RR}=\mathrm{ER}-\mathrm{BR},
$$

where $\mathrm{NBR}$ is nonborrowed reserves, $\mathrm{RR}$ is required reserves, $E R$ is excess reserves, and $B R$ is borrowed reserves. (By transposing the negative terms, this relation is shown to be the identity "total reserves equal total reserves.") Because of lagged-reserve accounting, required reserves are given for a particular statement week. Given a projection for excess reserves, the weekly target for nonborrowed reserves then determines, via (2), a weekly target for borrowed reserves. Within a particular week, consequently, the desk uses nonborrowed reserves and borrowed reserves interchangeably as operating targets.

The Federal Reserve assesses its reserve targets each week. First, the staff of the Board of Governors makes adjustments to the nonborrowed-reserves and total-reserves targets in order to offset shifts in the ratio of reserves to checkable deposits. Estimates of this ratio change because of changes in estimates of excess reserves and of required reserves generated by the reservable nonmonetary liabilities of financial institutions. These adjustments alter the desk's target for total reserves and nonborrowed reserves by equal amounts. Consequently, neither the average target nor the weekly targets for borrowed reserves are affected. In conjunction with a revised projection of money-supply growth, a projection is made of the average amount of total reserves that will be outstanding over the current targeting interval. The desk subtracts its target for average nonborrowed reserves, adjusted as just described, from this newly revised estimate of average total reserves in order to arrive at a new target for average borrowed reserves. The desk then derives a new weekly borrowedreserves target.

As a consequence of targeting nonborrowed reserves, deviations of the money supply from its targeted path produce, via associated movements of total reserves, changes in borrowed reserves. Changes in borrowed reserves, in turn, produce changes in the

5 The Federal Reserve uses the language "initial assumption for borrowed reserves." It is felt that the word "assumption," rather than "target," conveys more of the sense of the practice of changing this variable when misses of money-supply targets occur. funds rate that mitigate the miss from the moneysupply target. The Federal Reserve can also make discretionary changes in its operating targets in response to misses of the money-supply target. It can, at FOMC meetings, raise or lower the initial target for average borrowed reserves relative to the prevailing level, thereby lowering or raising the initial target for average nonborrowed reserves. ${ }^{6,7}$ The desk can change the target for average nonborrowed reserves between FOMC meetings. Finally, the discount rate can be changed. ${ }^{8}$ (See [3] for an alternative description of these operating procedures.)

\section{The Behavior of the Money Supply in $\mathbf{1 9 8 0}$}

As indicated by Figure 2, the rate of growth of the money supply, measured by M1B, was extremely variable within 1980 . The analytical framework of Section II is used in order to explain this behavior. ${ }^{9}$ M1B grew rapidly from the end of 1979 through

${ }^{6}$ In setting this target, the FOMC appears most of ten in 1980 to have taken the target for average borrowed reserves that was in force going into a particular FOMC meeting and to have set the new target equal to this existing target, after an adjustment for recently observed shifts in the reserve supply schedule. For example, if the last weekly observation available indicated that realized borrowed reserves had fallen without any change in the funds rate, then the new initial target for borrowed reserves would have been set somewhat below the currently prevailing target.

7 In the face of a miss of the money-supply target, the FOMC at a given meeting will also move the nonborrowed-reserves target in the appropriate direction by retaining the existing intrayearly target for the money supply and by adopting the target for borrowed reserves that existed going into the FOMC meeting. Consider an overshoot of the money supply. This overshoot will have caused the target for average borrowed reserves to increase, relative to the initial value set at the prior FOMC meeting. Leaving the money-supply target path unchanged will leave the target for total reserves essentially unchanged. Subtracting the increased target for borrowed reserves from the essentially unchanged target for total reserves will lower the target for average nonborrowed reserves, relative to the value set at the prior FOMC meeting.

8 The Federal Reserve could use alterations in the required-reserve ratio against checkable deposits as an operating variable. The alterations in the way required reserves are computed that have occurred since October 1979 (apart from changes mandated by the Monetary Control Act) have involved the nonmonetary liabilities of banks, however, and have been designed to control, through an excise-tax effect, the extension of credit, not money. The nonborrowed-reserves target has always been adjusted in order to offset the changes in required reserves arising from such alterations in reserve requirements.

9 The primary empirical test of the analytical model is whether it is useful in understanding the actual behavior of the money supply. Confidence in the model will come only after extended successful application of it. 
Figure 2

\section{TARGETED AND ACTUAL BEHAVIOR OF M1B OVER 1980}

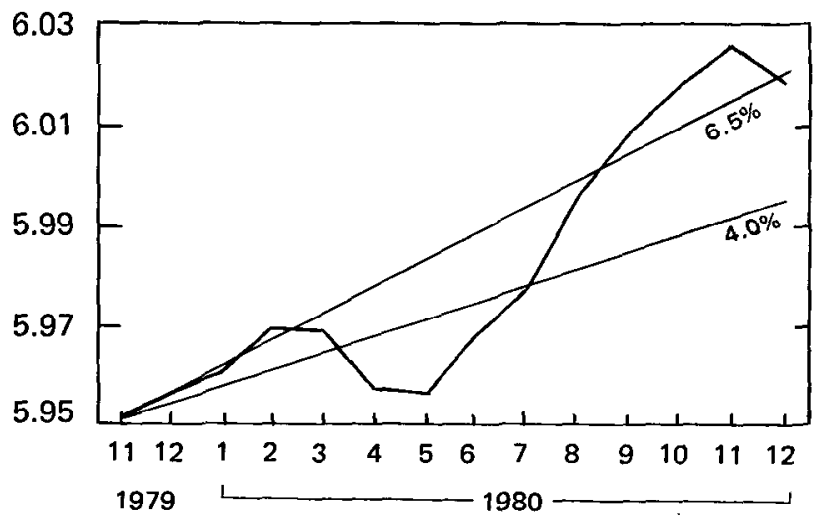

NOTE: The target range for growth of M1B from fourth quarter 1979 to fourth quarter 1980, specified by the FOMC in February 1980, was 4 to $6 \frac{1}{2}$ percent. The base and final values are plotted in November of 1979 and 1980, respectively. The cone plots interpolated values. The realized values for MIB were taken from the Federal Reserve statistical release H.6, dated 1/9/81. Logarithmic values are plotted.

February 1980. This growth derived from a rightward shift in the bank-credit demand schedule, which in turn derived from an optimistic revision by the public of its estimate of the strength of the economy. This optimistic revision was prompted by the strength of incoming data on the real sector, which belied the prevalent forecast of a recession, and by increased estimates of defense spending following the Soviet invasion of Afghanistan in December 1979. (The rightward shift in the bank-credit demand schedule is shown in Figure 3b by the movement of $\mathrm{BCD}$ to $\mathrm{BCD}^{\prime}$.)

The president's budget message in late January was viewed as avoiding hard choices between defense and domestic spending and, consequently, as presaging continued large budget deficits. This prospect, as well as the belief that recession was no longer imminent, caused the public to revise upward its near-term and long-term expectations of the inflation rate. As a consequence, the bank-credit demand schedule, defined as a function of the nominal rate of interest, shifted upward (rightward). An increase in the expected rate of inflation, however, does not affect the position of the reserve-supply schedule and, thus, does not in itself raise the cost of reserves to banks.

The rightward shifts in the bank-credit demand schedule described above caused bank credit and deposits to increase, in the first instance at an unchanged funds rate. With a two-week lag, the increase in deposits caused the reserve-demand schedule to shift rightward. Given the target for nonborrowed reserves, and thus a fixed reserve supply schedule, the rightward shift in the reserve demand schedule caused borrowed reserves and the funds rate
Figure 3a

\section{RESERVES MARKET}

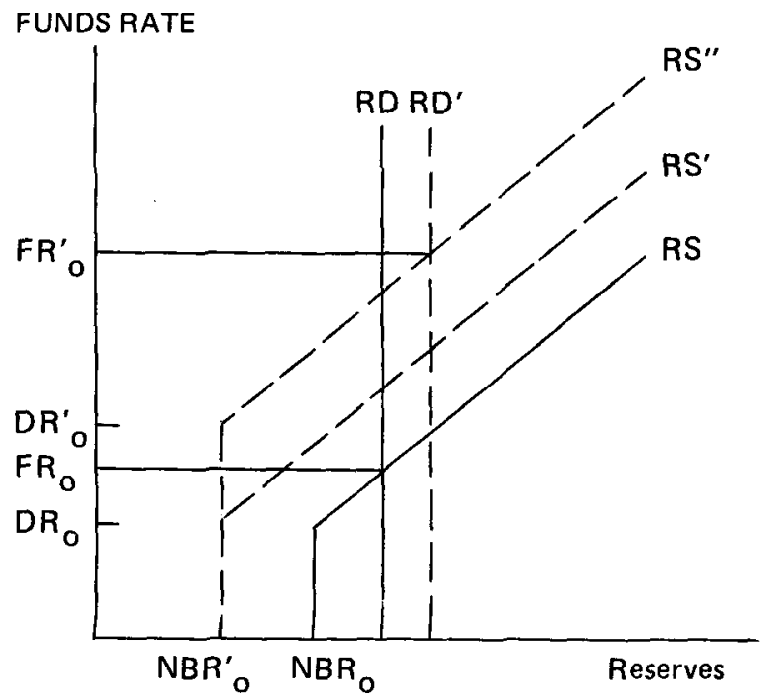

Figure 3b

\section{BANK CREDIT MARKET}

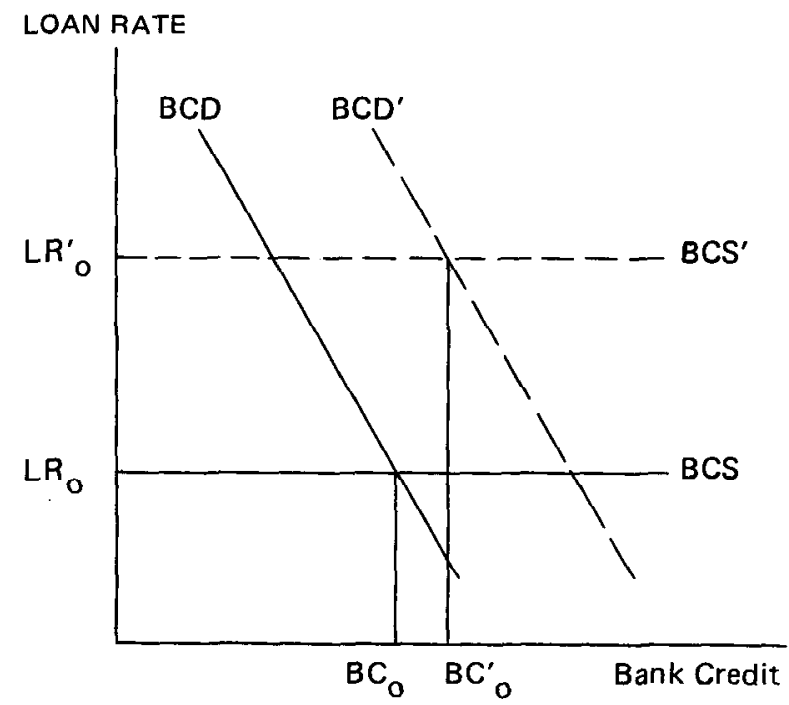

NOTE: Labels are explained in Figure 1 . 
to rise. The rise in the funds rate partially offset, but did not eliminate the overshoot in the Federal Reserve's intrayearly money-supply targets. (The demoralization of the bond market in February also affected the behavior of the moncy supply, but discussion of this phenomenon is reserved for later in this section.)

The Federal Reserve responded to this overshoot by moving its operating targets vigorously in late February and early March. ${ }^{10}$ The target for average nonborrowed reserves was lowered twice. (This lowering is shown in Figure 3a by the leftward shift of $\mathrm{NBR}_{0}$ to $\mathrm{NBR}_{0}{ }^{\prime}$ and by the associated shift in the reserve-supply schedule from $\mathrm{RS}$ to $\mathrm{RS}^{\prime}$.) The discount rate was raised a percentage point (shown in Figure 3a by the upward shift in RS' to RS'). The annualized rate of growth of M1B was reduced from 7.7 percent from December to February to 5.2 percent from December to March, almost exactly the midpoint of the Federal Reserve's four-quarter target range for growth of M1B. (Figures $3 \mathrm{a}$ and $3 \mathrm{~b}$ show the final level of bank credit, $\mathrm{BC}_{0}{ }^{\prime}$, only slightly above its original level, and the associated reserve-demand schedule, $\mathrm{RD}^{\prime}$.)

From March through May, the annualized rate of growth of M1B fell to -7.4 percent. This monetary deceleration was produced by the Special Credit Restraint Program (SCRP), announced March 14. The immediate objective of the SCRP was to reduce the

10 The documentation of this section necessarily depends upon the publicly available sources of information concerning the operating targets of the Federal Reserve. As background, it is noted that before October 1979, the operating target of the Federal Reserve was the Federal funds rate. With a lag of about a month, the public was informed, in the Record of Policy Actions, of the initial value specified by the FOMC for this operating target, of subsequent changes in the targeted value, and of the reasons these changes occurred. In October 1979, nonborrowed reserves replaced the funds rate as the Federal Reserve's operating target. At this time, the Record of Policy Actions ceased reporting any information about the operating target. It also ceased to be a complete summary of FOMC policy actions due to omission of any mention of the FOMC's initial target for average borrowed reserves.

The only publicly available source of this information is the annual report of open market operations published in the Federal Reserve Bank of New York Quarterly Review (generally) in August of the succeeding year. This report, however, is intended for a general audience, not jist students of the money-supply process. It does not necessarily provide for a sharp distinction, critical for the purpose of this article, between those changes in the targets for nonborrowed reserves that should be considered as "technical" and those that should be considered as significantly influencing the behavior of the money supply. The documentation then for this section rests on the material in [9], but the author has exercised some judgment as to which of the changes in the targets for nonborrowed reserves listed there were significant for purposes of monetary control. rate of growth of credit in general and bank-credit in particular, as evidenced by the fact that prior to the announcement of the program growth of the money supply (M1B) was approximately on target. Because the nominal quantities of bank credit and checkable deposits are functionally related, they cannot be targeted independently. Ordinarily, the Federal Reserve accepts the consequences of its money-supply targets for the rate of growth of nominal bank credit; however, this situation was reversed to a significant extent after March 14. The SCRP acted in several specific ways to produce a monetary deceleration.

One feature of the SCRP was a surcharge of three percentage points over the discount rate applied to "frequent" use of the discount window by banks with deposits in excess of $\$ 500$ million. (The surcharge itself, because of its application to only a subsct of member banks, complicated monetary control by rendering the behavior of the reserve-supply schedule even less predictable.) A scatter diagram of borrowed reserves against the differential between the funds rate and the discount rate (a graphical estimate of the upward-sloping section of the reservesupply schedule) indicates that, after the surcharge, the interest rate differential associated with a given amount of borrowed reserves increased by about three percentage points. It is uncertain, however, how much of the increase in the differential was due to the dircet effect of the surcharge. The increase could have been caused by an upward rotation of the upward-sloping section of the reserve-supply schedule due to the effect of tough Federal Reserve rhetoric on banks' perception of the nonpecuniary costs associated with use of the discount window. In any event, the sharp increase in the funds rate produced by the surcharge reduced the rate of growth of the money supply.

The SCRP also compelled banks to hold loan growth to within 6 to 9 percent. Because of strong loan growth in January and February, and because of the possibility that corporations would make use of outstanding lines of credit, banks were fearful of exceeding the guidelines. This fear had the effect of causing banks to increase the differential between the rate on bank loans and the funds rate and money market rates. A result was to shift intermediation to the money market from banks. The consequent reduction in bank credit depressed bank deposits and the money supply. Also, the psychological effect of the SCRP caused the public to reduce its use of credit. Installment credit contracted at a seasonally adjusted annual rate of 7.5 percent in April and 13 percent in both May and June, causing the bank- 
credit demand schedule to shift leftward. Finally, as the public became convinced that a significant recession was underway, it lowered its inflationary anticipations and the bank-credit demand schedule shifted downward (leftward). These shifts in the bankcredit demand schedule depressed the money supply.

The Federal Reserve apparently did not realize initially that its targets for bank credit and the money supply would conflict. At its March and April meetings, the FOMC extended the target for M1B in line with the targets of previouc meetings. (Only starting with the May meeting did the FOMC begin to lower its M1B targets.) ${ }^{11}$ The resulting targets for nonborrowed reserves, in combination with the reduced demand for total reserves associated with the drop in the money supply, produced a sharp drop in borrowed reserves and in the funds rate. The weekly average value of the funds rate dropped about ten percentage points from early April to late May.

From May through August, M1B grew at an annualized rate of 16.9 percent. A distinguishing characteristic of this period is that for the statement weeks

11 At its March and April meetings, the FOMC set an intrayearly target for growth of M1B designed to place $\mathrm{M} 1 \mathrm{~B}$ at the midpoint of its four-quarter target cone, shown in Figure 2, by June. At the May neeting, it set an intrayearly target for M1B designed to achieve the midpoint of its target cone only by year-end. At the subsequent meeting in July, it set an intrayearly target for M1B designed to place M1B at the bottom of its target cone by year-end. (See the Record of Policy Actions of the Federal Open Market Committee in [1] for March, p. 110, for April, p. 118, for May, p. 123, and for July, pp. 130 and 131.)

Figure 4a

\section{RESERVES MARKET}

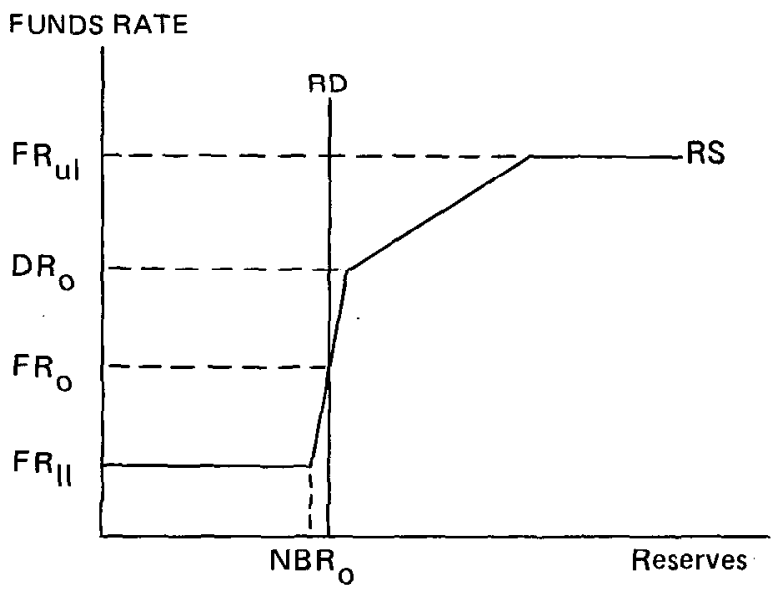

ending May 7 through August 20, the weekly average value of the funds rate was below the discount rate. At least through early August, the funds rate implied by the FOMC's money-supply target was also below the discount rate. In order to understand the Federal Reserve's operating procedures over this interval, it is necessary to alter in two ways the reserve-supply schedule shown in the diagram representing the reserves market. First, the reserve-supply schedule is horizontal at the lower and upper limits of the FOMC's tolerance range for variation in the funds rate. $^{12}$

For banks either borrowing late in the day or already borrowing significant amounts of fed funds, the cost of borrowing funds can exceed the value of the funds rate at which most trades arc occurring. For these banks, this differential can be large enough that it is advantageous to use the discount window even when the generally prevailing funds rate lies below the discount rate. This borrowing increases the supply of reserves beyond nonborrowed reserves even when the funds rate lies below the discount rate. The phenomenon is shown in Figure 4a by the positive, but highly inelastic, slope of the reserve-supply schedule immediately to the right of the existing value of nonborrowed reserves, $\mathrm{NBR}_{0}$. Above the discount rate, $\mathrm{DR}_{0}$, the reserve-supply schedule exhibits the relatively more elastic slope shown in the previous diagrams.

12 The Federal Reserve describes the limits as "points for Committee consultation." 
For the pcriod from May 7 through August 20, the Federal Reserve lost the ability to use nonborrowed reserves as an operating target. Over this interval, the reserve demand schedule intersected the reservesupply schedule along the latter schedule's inelastic section, so that the funds rate lay below the discount rate (see Figure 4a). In this situation, an increase in nonborrowed reserves, a rightward shift of the reserve-supply schedule, would have forced the funds rate down to the lower limit of its tolerance range, thereby making the funds rate the desk's operating target. A decrease in nonborrowed reserves, a leftward shift of the reserve-supply schedule, would have forced the funds rate up to the discount rate, a value in excess of what was implied by the money-supply target. ${ }^{13}$

At the May and July FOMC meetings (there was no June meeting), the FOMC set minimum targets for growth of the money supply. Growth moderately above target was to be accommodated by the desk. In fact, the money supply did grow somewhat faster than the minimum targeted values. The desk caused the reserve-supply schedule to shift in line with the rightward shifts in the reserve-demand schedule by targeting a vcry small level of borrowed reserves. (Toward the end of July, the desk stopped raising its target for nonborrowed reserves, but its projections of the money supply and total reserves apparently caused it to continue to target only a small amount of borrowed reserves.) As shown in Figure 2, from May through August, M1B moved from well below to the upper part of its target cone. This desired result, however, was not accomplished by active manipulation of nonborrowed reserves, but rather by the vagaries of shifts in the bank-credit demand schedule.

From August to November, M1B grew at an annualized rate of 12.9 percent. Money-supply growth exceeded its targeted values from late summer through the December 19 FOMC meeting. As a consequence, M1B grew at a rate of 7.3 percent

\footnotetext{
13 In order to have retained nonborrowed reserves as the operating target, the Federal Reserve would have had to lower both the discount rate and its target for nonborrowed reserves (shift the RS schedule downward and leftward). In this way, the relatively elastic section of the reserve-supply schedule would again have intersected the reserve-demand schedule, so that either changes in the nonborrowed-reserves target or in the reserve demand schedule would not have forced the funds rate to the limit of its tolerance range. The Record of Policy Actions for the May FOMC meeting records a concern that further declines in short-term rates would exacerbate inflationary expectations and weaken the foreign-exchange value of the dollar $[1, \mathrm{p} .123]$. This concern can be inferred to have limited willingness of the Federal Reserve to lower the discount rate and thus to have accounted for the summer's operating procedures.
}

between the fourth quarters of 1979 and 1980, somewhat in excess of the top of its targeted range. Beginning in the summer, the economy rebounded strongly from the depressing effects of the SCRP. The public reduced its estimate of the length and the severity of the current recession and increased its estimate of the future rate of inflation. As a result of these events, the bank-credit demand schedule shifted rightward and bank deposits increased. The Federal Reserve, by holding to its nonborrowed-reserves targets in the face of a rightward shifting reservedemand schedule, caused borrowed reserves and the funds rate to increase, thereby moderating, but not eliminating, the overshoot of the money supply. ${ }^{14}$

The Federal Reserve made discretionary changes in its operating targets only belatedly. In particular, it did not, to any meaningful extent, lower its targets for nonborrowed reserves. ${ }^{15}$ As an alternative to reductions by the desk in the target for nonborrowed reserves, the FOMC could have increased the initial targets for average borrowed reserves, relative to the

14 Initially, however, this mechanism was a weak reed. "The rise in borrowings from frictional levels to over $\$ 1$ billion between mid-Angust and mid-September may have been rapid by past standards, but the resulting increase in the federal funds rate of about $5 / 8$ percentage point appeared small to the market in relation to the overshoots reported weekly in the money supply" $[8, p$. $34]$.

15 In the period from September through December, the desk reduced the target for average nonborrowed reserves in four targeting intervals for reasons unrelated to a revision in the estimated relationship between reserves and checkable deposits. Such reductions in the target for average nonborrowed reserves do not necessarily increase the funds rate, however. First, they do not if they are caused by the problem that can arise from expressing reserves targets as averages. In particular, an overshoot in borrowing in the first part of a targeting interval can cause the desk to lower its weekly target for nonborrowed reserves in order to prevent the appearance of excess reserves large enough to force a sharp drop in the funds rate. Achievement of the target for average nonborrowed reserves over the remainder of the targeting interval can then require weekly targets for nonborrowed reserves that imply little or no borrowing. In such cases, the desk may reduce the target for average nonborrowed reserves in order to keep the weekly targets for borrowed reserves from declining significantly. (See [9], p. 65 and the discussion surrounding the September reduction in the target for nonborrowed reserves, p. 73.) Second, a reduction in the target for average nonborrowed reserves will not increase the funds rate if a reduction in the target for average nonborrowed reserves called for by a concursent downward revision in the estimated reservesdeposits ratio is not also effected. In such a case, the rise in the target for average borrowed reserves and in the funds rate is nullified. Finally, the effect of a reduction in the target for average nonborrowed reserves can be of ${ }^{2}$ sel if, at the subsequent FOMC meeting, the initial target for average borrowed reserves is lowered significantly relative to the target prevailing at the time of the meeting. Reductions in the target for average nonborrowed reserves acted unambiguously to decrease growth of the money supply only after the November 18 FOMC meeting. 
targets prevailing at the time of its meetings, but did not. Alternatively, as explained in note 6 , the FOMC, at its meetings, could have adopted the prevailing target for borrowed reserves, while leaving unchanged its money-supply target. In fact, over most of the last half of 1980 , the FOMC raised its moneysupply target in response to overshoots. ${ }^{16}$ The discretionary changes in operating targets that did occur after July were essentially confined to three one percentage-point increases in the discount rate (on September 26, November 17, and December 5). In the second instance, a surcharge of two percentage points was imposed on "frequent" borrowing by large banks. In the third instance, the surcharge was increased to three percentage points.

The uncertainty surrounding the inflation forecasts of market participants increased in the summer for two reasons. The midyear review of the federal budget and renewed talk of large tax cuts caused deficits of significant, but unpredictable, size to appear likely in the future. Also, the unanticipated pickup of economic activity rendered forecasts of the business cycle unusually difficult. Starting in September, borrowers and lenders became, to a significant extent, unwilling to commit themselves to longterm, fixed-income securities. Borrowers who would have used the bond market turned to commercial banks, causing the bank-credit demand schedule to shift rightward.

If the lenders who left the bond market had acquired the nonmonetary liabilities of banks exclusively (for example CD's), this rightward shift in the bank-credit demand schedule would have been matched by a rightward shift in the demand schedule for the nonmonetary liabilities of banks. Total and nonmonetary deposits would have increased by the same amount with no effect on checkable deposits (see n. 3). Former lenders in the bond market, however, must have placed at least some of their funds, perhaps temporarily, in checkable deposits.

\footnotetext{
16 At the July FOMC meeting, the targeted four-quarter rate of growth of M1B was set close to the lower bound of the four-quarter target range, 4 to $6 \mathrm{t} / 2$ percent. "The FOMC is in fact prepared to consider that M $1 \mathrm{~B}$ measures may fall significantly short of the mridpoint of their specified ranges for the year" [11, p. 638]. At the September and October meetings, the targeted fourquarter rate of growth of MIB was, respectively, set close to and somewhat above the upper bound of the fourquarter target range. (A revision of the estimate of growth of NOW and ATS accounts that was coming at the expense of savings deposits accounted for half a percentage point of this rise $[1$, pp. 143,149$]$.) At the November meeting, the targeted four-quarter rate of growth of M1B was left unchanged, but the initial target for average borrowed reserves was lowered relative to its prevailing value at the time of the meeting.
}

Others must have purchased money market instruments such as Treasury bills, thereby increasing at least temporarily the checkable deposits of the sellers of these instruments. The result was that the rightward shift in the bank-credit demand schedule was only partly matched by a rightward shift in the public's demand schedule for the nonmonetary liabilities of banks, and therefore checkable deposits increased.

The Federal Reserve delayed making discretionary changes in its operating targets in response to the resurgent growth of the money supply. It is conjectured here that this delayed response imparted a selfreinforcing character to money-supply growth in the last part of 1980. As argued above, the reduction of intermediation via the bond market increased the rate of growth of the money supply. This monetary acceleration increased the public's uncertainty surrounding the future inflation rate. This increased uncertainty, in turn, further reduced activity in the bond market and, conscquently, reinforced onc of the impulses toward an increased rate of growth of the money supply. ${ }^{17}$

\section{Summary and Conclusions}

Several reasons were advanced in Section $\mathrm{V}$ for the variability of money within 1980 . One was that in the spring the Federal Reserve employed bank credit as an intermediate target. In the fall in particular, the Federal Reserve responded to misses in its money-supply targets by relying primarily on the semiautomatic corrective forces set in motion through maintenance of a given target path for nonborrowed reserves. It can be inferred that a necessary condition for the Federal Reserve to achieve its intrayearly money-supply targets is frequent alteration of its operating target, nonborrowed reserves. It was contended in Section III that the combination of reserveaggregate targeting and lagged-reserve accounting has produced a regime of monetary control based on unpredictable behavioral relationships. This situation creates the possibility that monetary control would be enhanced by a regime based upon contemporaneousreserve accounting and a total-reserves operating target.

\footnotetext{
17 It is frequently argued that short-run control of the money supply will increase interest-rate variability. In the situation just discussed, however, if the Federal Reserve had achieved its short-run money-supply targets, it might have limited the demoralization of the bond market caused by heightened uncertainty over future inflation. Short-term interest rates would not have had then to rise as high as they did ultimately in order to control the money supply.
} 


\section{APPENDIX}

Consider first a New View world. The monetary authority is assumed to increase nonborrowed reserves in order to lower the funds rate by an amount that produces a reduction in the loan rate from $L R_{0}$ to $\mathrm{LR}_{0}{ }^{\prime}$ and a reduction in the rate on money market instruments from $R_{0}$ to $R_{0}{ }^{\prime}$ (see Figure 5). The reduction in the loan rate causes bank credit to increase from $\mathrm{BC}_{0}$ to $\mathrm{BC}_{0}{ }^{\prime}$. As a consequence of the balance sheet constraint relating bank credit and deposits, deposits increase from $\mathrm{D}_{0}$ to $\mathrm{D}_{0}{ }^{\prime}$. Under the assumption that the magnitude of the slope of the demand schedule in the credit market exceeds that of the demand schedule in the deposits market, deposits of $\mathrm{D}_{0}{ }^{\prime}$ and a rate on money market instruments of $\mathrm{R}_{0}{ }^{\prime}$ produce excess supply in the deposits market of $\mathrm{ES}_{0}$. This excess supply causes the nonbank public to purchase bonds. These purchases, in turn, cause the bank-credit demand schedule to shift leftward. (This shift is shown in Figure 5a by the dashed line.) At the loan rate $\mathrm{LR}_{0}{ }^{\prime}$, bank credit falls to $\mathrm{BC}_{0}{ }^{\prime \prime}$ and deposits fall to $\mathrm{D}_{0}{ }^{\prime \prime}$, the latter quantity lying on the unchanged deposits demand schedule of the nonbank public.

The primary constraint facing the monetary authority when it alters the nominal quantity of deposits

\section{Figure 5a}

\section{BANK CREDIT MARKET}

LOAN RATE

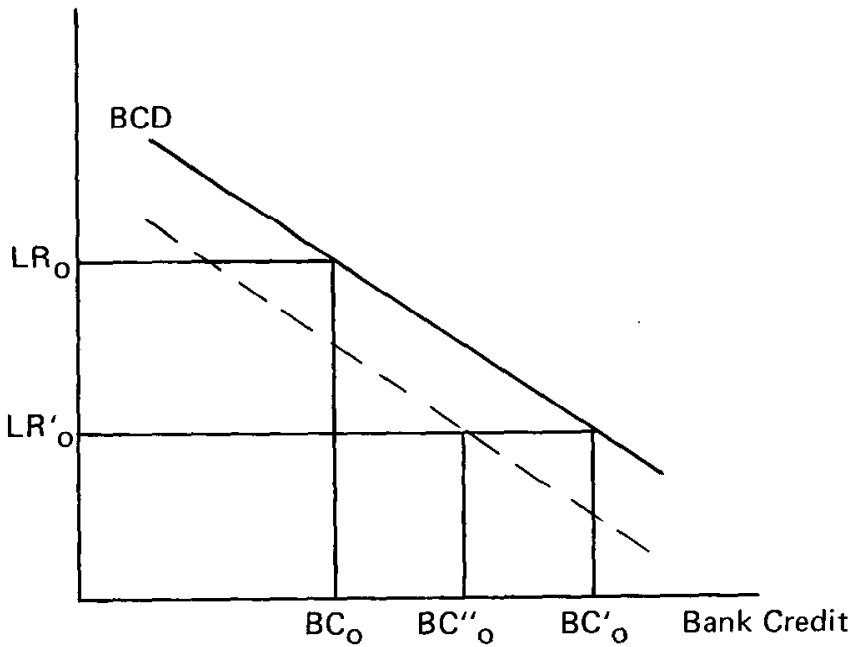

by a given amount is the deposits demand schedule of the nonbank public. The bank-credit demand schedwle will shift in order to cause the associated change in bank credit to produce the same change in the interest rate in the bank credit market as was produced in the market for the quantity of money. Empirically, the New View requires that liquidity preference be the primary determinant of interest rates over short intervals of time. Heuristically, the New View makes alterations in the money supply by the monetary authority into exercises in persuading the nonbank public to rearrange its asset portfolio.

The Old View starts from the perspective of money not as an asset, but rather as a medium of exchange, that is, as a buffer to asynchronous receipts and expenditures. As a consequence of this role, the quantity of money individuals hold changes continually without any economically significant change in their demand for money. The monetary authority, in effect, exploits this phenomenon in altering the public's money balances without at the same time altering its demand for money balances, that is, without having to move the nonbank public along its money demand schedule. With reference to the above example, the behavior of hank credit determines a
MONEY MARKET

RATE

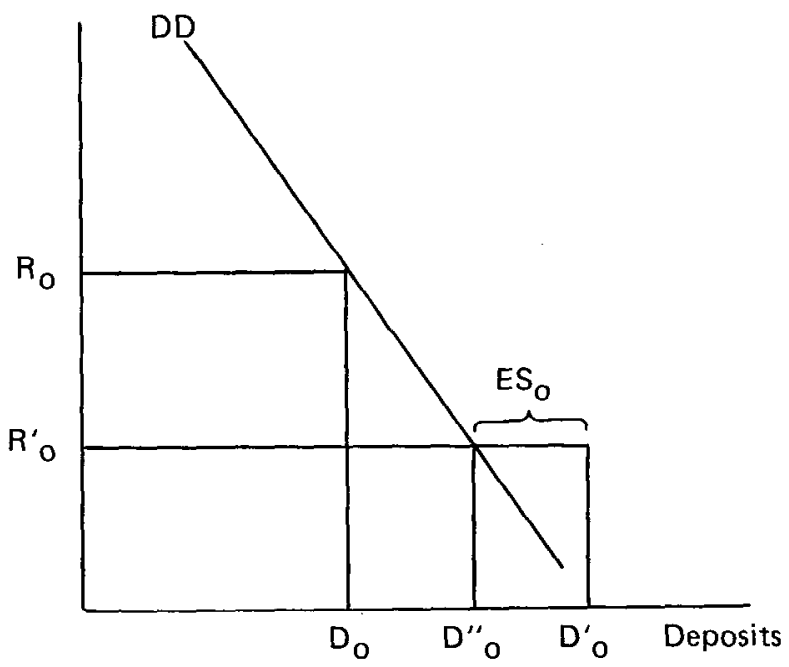

$R$ is the interest rate on money-market instruments; $D$ checkable deposits; $D D$ the deposit demand schedule of the nonbank public. Other labels are explained in Figure 1. 
nominal quantity of deposits (the endpoint of the horizontal line drawn at $R_{0}{ }^{\prime}$ in Figure $5 b$ ) that is given to the market for the quantity of money. Individuals are concerned about their average holdings of money balances. Because of the normal variability in their money holdings, some time may have to elapse before they realize that their actual average holdings of money exceed their desired average holdings. When this realization occurs, aggregate spending will increase as individuals try to run down their cash balances.

Economic activity will be stimulated, and in time the price level will rise. While the nominal money balances of the public are determined in the market for bank credit, its real money balances are determined in the market for the quantity of money. The initial increase in real economic activity will cause the bank-credit demand schedule to shift rightward, and if the public comes to anticipate a higher rate of inflation, the bank-credit demand schedule will shift upward. Empirically, it is these latter shifts that the Old View emphasizes, rather than the leftward shift due to a liquidity preference effect that is emphasized by the New View. (The New and Old View both are in accord that the nonmonetary liabilities of banks are demand determined. See note 3.)

Finally, the bank-credit demand schedule could shift frequently as a consequence of shifts in the deposits demand schedule. In this case, even if as an empirical matter liquidity preference as a determinant of interest rates is weak, the New View is relevant and the deposits demand schedule replaces the bankcredit demand schedule as the primary behavioral constraint facing the monetary authority. The Old View assumes that to a significant extent the shocks that impinge on the market for bank credit are real, rather than monetary, in origin.

\section{References}

1. Board of Governors of the Federal Reserve System. 67th Annual Report, 1980.

2. Burger, Albert E. The Money Supply Process. Belmont, Calif.: Wadsworth Publishing Co., 1971.

3. Coats, Warren L., Jr. "Recent Monetary Policy Strategies in the United States." Kredit und Kapital, (October-November 1981).

4. Goodfriend, Marvin S. "Discount Window Borrowing, Monetary Control, and the Post-October 6 , 1979 Federal Reserve Operating Procedure." Federal Reserve Bank of Richmond, 1981, processed.

5. Hetzel, Robert L. "The Federal Reserve System and Control of the Money Supply in the 1970s." Journal of Money, Credit, and Banking, 13 (February 1981) : 31-43.

6. Laurent, Robert D. "A Critique of the Federal Reserve's New Operating Procedure." Federal Reserve Bank of Chicago, 1981, processed.
7. Levin, Fred J. "Examination of the Money-Stock Control Approach of Burger, Kalish, and Babb." Journal of Money, Credit, and Banking, 5 (November 1973): 924-38.

8. Levin, Fred J., and Paul Meek. "Implementing the New Operating Procedures: The View from the Trading Desk." In Board of Governors of the Federal Reserve System, "New Monetary Control Procedures." Vol. 1 (February 1981).

9. "Monetary Policy and Open Market Operations in 1980." Quarterly Review, Federal Reserve Bank of New York, 6 (Summer 1981) : 56-75.

10. Volcker, Paul A. "Statement" before the Joint Economic Committee of the U. S. Congress, February 1, 1980 . In Federal Reserve Bulletin, 66 (February 1980): 137-43.

11. - "Statement" before the Budget Committee, U. S. Senate, July 24, 1980. In Federal Reserve Bulletin, 66 (August 1980): 636-40. 


\title{
INTEREST RATES AND FEDERAL DEFICITS
}

\author{
Roy H. Webb
}

The relationship of Federal deficits and market interest rates has been the central theme of much recent discussion of economic policy. To many discussants it is axiomatic that Federal deficits determine interest rates. For example, as a bank chairman put it "[Deficits] are the major reason that our interest rates stay close to record high levels." (American Banker [5, p. 2]) And a trade group asserted, "More than anything else, it is the spectre of an overwhelming volume of deficit financing which haunts housing and financial markets." (Wall Street Journal $[8$, p. 8])

Those and similar statements tend to take the asserted deficit-interest rate relationship as selfevident, and thus do not include theory or evidence to support their claims. Yet a casual glance at recent American data fails to provide a clear contemporaneous link between deficits and interest rates. In fact, Figure 1 indicates that in 1975, when the deficit was at its highest level in several decades, there were neither high nor rising interest rates. While such evidence does not rule out any linkage of deficits and interest rates, at the very least the data suggest the existence of other important factors.

In order to clarify the effects of deficits, this article takes a closer look at the theoretical relation between fiscal actions and interest rates. Although the analysis indicates that a relation does exist, it also points out reasons that actual interest rate effects are likely to be less drastic than much of the current discussion assumes. Before presenting that analysis, however, it is useful to consider whether the reported Federal deficit is indeed a meaningful figure.

\section{Measuring Federal Debt}

In general terms, the Federal debt is the outstanding volume of Federal obligations, whereas the deficit is the volume of expenditures minus tax receipts. As a matter of arithmetic, the deficit (over an interval of time) is exactly equal to the sum of changes in the debt and the monetary base. Assuming for simplicity that there is no change in the monetary base, the deficit is just the change in the debt. Note that the debt is a fixed number at any point in time, and is often referred to as a stock. The deficit, however, being the change in a stock, is only meaningful over an interval of time and is referred to as a flow. The stock-flow distinction is important to keep in mind in order to appraise the size of the debt or deficit over time. Comparisons of nominal magnitudes over time can be difficult to interpret due to growth in the price level, as well as fluctuations in real output. Therefore ratios of nominal variables are often used to provide some perspective. For example, the ratio of Federal debt to total debt compares stocks, while the ratio of the deficit to private saving compares flows. As Figure 1 indicates, the deficitsaving ratio in the fourth quarter of 1981 was slightly below 20 percent, compared to a much larger 33 percent in early 1975 . In contrast, the $\$ 100$ billion deficit reported for late 1981 appears much larger when considered by itself.

Once the stock-flow distinction is made, there are further ambiguities. Consider first the stock of Federal debt. Although usually stated at par value (that is, the price when issued), market value may be more relevant to individuals' financial decisions and thus to interest rates. By one estimate (data in this paragraph are from the Council of Economic Advisers [3]) the difference between market value and par value was $\$ 65$ billion in 1980 . N1so, since the Federal government holds substantial financial assets, it may be the case that liabilities minus assets, i.e., net liabilities, could be more relevant than the commonly reported gross liabilities. In 1980, net liabilities of the Federal government were less than half of gross liabilities. But those figures ignore explicit and implicit promises of future Federal spending that may also affect the supplies of and the demands for financial assets, thereby affecting interest rates. For example, unfunded social security liabilities have been estimated at more than $\$ 4$ trillion, not to mention government-guaranteed loans and deposit insurance from Federal agencies. Perhaps the present value of these spending commitments should be included in the reported Federal debt. The problem of whether or not to include them points up the lack of an unambiguous measure of the Federal debt. 
Figure 1

THE FEDERAL DEFICIT AND INTEREST RATES

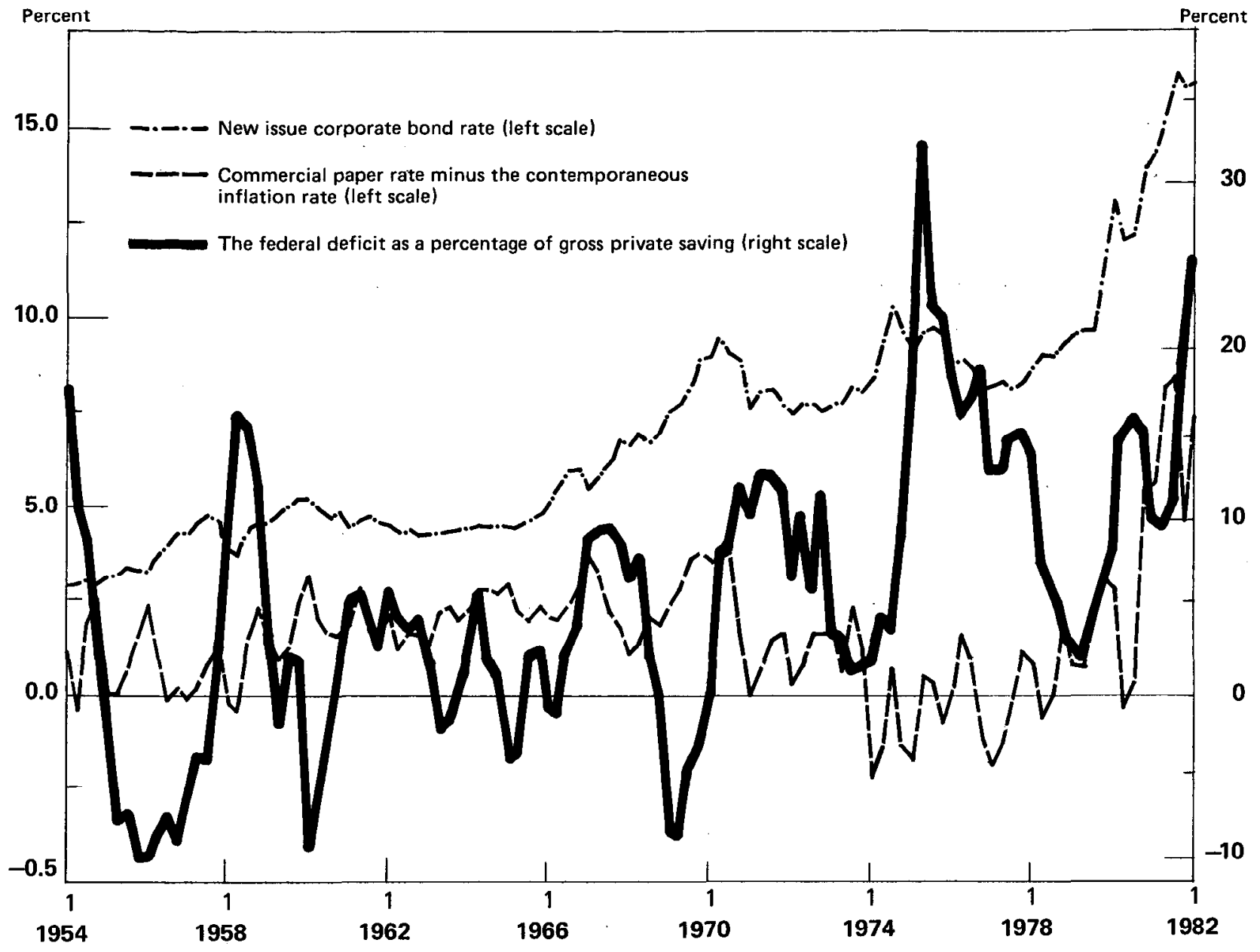

And since the Federal deficit is the change in the stock of Federal debt minus the change in the monetary base, the meaning of reported deficits is also open to question.

Even assuming that the deficit is estimated without ambiguity, other problems remain. For one, the deficit is often compared with personal saving taken from the National Income and Product Accounts (NIPA). That estimate, however, is created as a residual-personal income minus outlays. Therefore any error in income or spending is magnified when saving is estimated. For example, had personal income in 1981 been underestimated by 1 percent and consumption estimated precisely, there would have been an 18 percent underestimate of personal saving.

Moreover, some analysts contend that saving minus depreciation, or net saving, is a more relevant value. But NIPA depreciation is not a precise magnitude measuring actual transactions. Instead, a large num- ber of assumptions are made in order to use gross investment data, which do represent actual transactions, to estimate the magnitudes of capital stocks (see Young and Musgrave [9, pp. 23-82]). Then depreciation patterns are also assumed and are applied to each constructed capital stock in order to estimate depreciation flows over specific time periods. Different assumptions can produce widely divergent estimates of capital stocks or depreciation flows. Yet there is little precise information concerning such factors as when and why firms discard capital assets, or how the productivity of various capital assets changes over time, and these are just some of the assumptions necessary to estimate capital stocks and depreciation patterns. Thus the resulting estimates of depreciation may well be substantially different from true depreciation, in turn making estimates of net saving subject to even greater measurement error than gross saving. 
In short, there is no easy resolution of the many ambiguities involved in comparing the current Federal debt or deficit to historical values. That fact alone should caution readers against accepting strong claims unless proponents supply supporting data that can be meaningful despite the measurement problems detailed above. The analysis in the next section uses a simple theoretical model that abstracts from such complications.

\section{Traditional Theory}

A traditional macroeconomic model is used in this section to illustrate why deficits could affect interest rates. Conventional models of this type invariably show that fiscal actions ${ }^{1}$ have a larger impact on interest rates when the economy is operating near full capacity than when substantial unemployment exists. Thus in order to illustrate the maximum deficitinterest rate effect, a full employment version of an IS-LM model will be used in this section (see Patinkin [7, ch. 12]). This model abstracts from the business cycle by assuming that real output is fixed (at full capacity) while prices are allowed to vary.

Perhaps the easiest way to use the model is with a graph such as Figure 2a. The object of using such models is to attempt to determine the qualitative effects of shocks to the economy by observing changes in macroeconomic equilibrium in the graphical model. The downward sloping line in the graph, labeled the IS curve, illustrates the combinations of the price level and the interest rate for which the demand for commodities is equal to the full-employment quantity supplied. The upward sloping LM curve illustrates the price-interest rate combinations for which the demand for money is equal to the quantity supplied. At the point of intersection of the two curves, demand equals supply in both the commodity and money markets; such a point is called a macroeconomic equilibrium.

The model can be used to illustrate the effect of a higher deficit. To be more specific, assume that (1) Federal taxes are lowered, (2) Federal spending does not change, (3) the tax cut was not anticipated, (4) no further change in fiscal policy is anticipated, (5) the quantity of money does not change, and (6) the quantity of money is not anticipated to change in the future. (These assumptions isolate purely fiscal

1 This article abstracts from a persistent problem, namely the best single magnitude to describe a fiscal action. The deficit is mentioned throughout the article because of its prominence in current policy discussion. It can be a misleading indicator of fiscal policy, however (see Blinder and Solow [2, pp. 11-33]). effects, avoiding monetary and expectational effects. $)^{2}$ The tax cut allows higher private spending; with government spending fixed, the result is a rightward shift in the IS curve in Figure $2 \mathrm{a}$. Accordingly, the new equilibrium is characterized by a higher price level ${ }^{3}$ and a higher interest rate.

\section{Interest Rates in an Open Economy}

One reason for believing that the model given above may overstate the importance of fiscal actions is that the American economy is but one element (albeit an important element) in a much larger world economy with well-integrated financial markets. Consequently, it is useful to think of a single world interest rate which equates supply and demand for the total stock of private and public debt in the world economy. That world rate would be unaffected by fiscal actions in a small, open economy. To see this, imagine that after a tax cut the domestic rate in such a small economy were to rise above the world rate. Then domestic borrowers could borrow more cheaply in other markets, thereby lowering domestic credit demand. Similarly, foreign lenders could do better by lending in domestic markets, consequently increasing credit supply. These actions would tend to eliminate any divergence of foreign and domestic rates in the small economy. Due to its size, however, American fiscal actions can alter the nominal supplies and demands for debt enough to alter the world interest rate. Nonetheless a deficit of a given magnitude represents a smaller percentage increase in the stock of world debt than in the stock of American debt. Accordingly, it affects interest rates by a lesser amount than would be projected for only the domestic economy.

A well-known analysis of the impact of fiscal actions in an open economy with flexible exchange rates was given by Mundell [6]. An adaptation of his analysis in Figure 2, shows the initial impact of a fiscal expansion to be a rightward shift of the IS curve, resulting in a higher domestic interest rate and price

\footnotetext{
2 By assuming no actual or anticipated money growth, the possibility of an anticipated, sustained inflation is also assumed away. That is, while a wide range of factors may cause one-time movements of the price level, as a practical matter a sustained increase in the money supply is the only source of price increases in the economy that is capable of a continual, rapid increase over a lengthy interval; accordingly, in the long run inflation is a monetary phenomenon. By omitting inflation, the model is simplified. But the omission of inflation also limits the model's current relevance.

3 This analysis follows tradition by assuming that Federal taxes are lump-sum taxes. As a result, substitution effects of a tax change on the price level are not considered.
} 
Figure 2

\section{QUALITATIVE EFFECTS OF A FEDERAL DEFICIT}

$2 a$

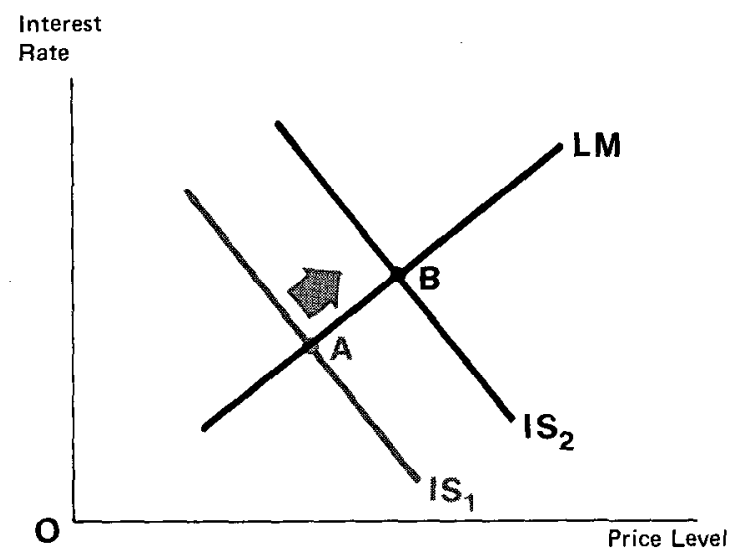

$2 b$

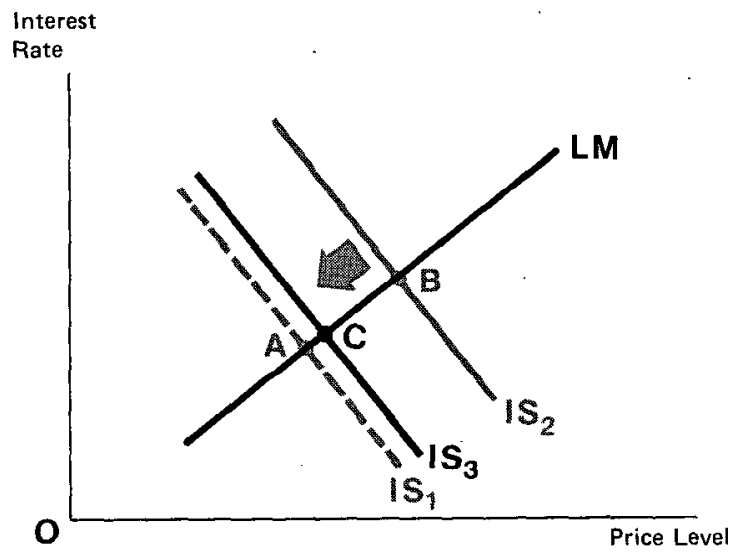

The rightward shift from $1 S_{1}$ to $1 S_{2}$ occurs due to a tax cut, as described in the text. As a result, the equilibrium values of the interest rate and price level also change as the economy moves from point $A$ to point $B$. The leftward shift from $\left[S_{2}\right.$ fo $1 S_{3}$ could occur if ( 1 ) government bonds are only partially perceived to be net wealth, or (2) the model represents a large, open econiomy.

level. Assuming no immediate price change by foreign economies, a higher domestic price level would dampen exports while spurring imports. At the same time, foreigners would be more willing to purchase domestic bonds due to the interest rate differential. All in all, the move toward lower net exports would result in a leftward shift in the IS curve. The ultimate effect would be for the IS curve to shift back to its original position for a small economy. For a large economy, however, the leftward shift would not be complete to the cxtent that the incrcase in debt of the large economy raised the world's supply of debt and thus the interest rate.

\section{Deficits and Consumer Behavior}

It is also possible for consumer behavior to offset some or all of the impact of a fiscal action (see, for example, Barro [1, pp. 1095-1118]). The basic idea is that consumption is based on consumers' permanent disposable income-which can be reduced either by current taxes or by future taxes. That is, when the government sells a bond, its buyer evidently believes that the present value of future interest payments and eventual principal repayment is at least as large as the current price of the bond. But if future debt service payment will be generated by future taxes, then (in a suitably simplified world) the present value of additional future tax obligations would be equal to the current price of a government bond. Therefore, financing a given level of government spending would lower aggregate permanent disposable income by the same amount, regardless of whether the spending were to be financed by current taxes or by current debt promising future taxes. And if aggregate disposable income did not change, neither would aggregate demand, the price level, nor the interest rate.

\section{Other Effects of Policy Anticipations}

A key assumption of the preceding section was that current deficits would lead to higher taxes in the future. Another possibility is that a higher deficit today would generate growth in the money supply in the future (for example, see McCallum [4]). Although Figure 3 does not reveal a simple historical relation between the deficit and Federal Reserve holdings of government debt, concerns about future monetary actions should not be summarily dismissed. There are historical examples in which a government reached a fiscal impasse, caused by political pressure groups inducing the government to spend at a high level without collecting sufficient taxes to avoid a sustained monetary acceleration. That is not to say that any single large deficit indicates that such a fiscal impasse is imminent. Rather, attention should be focuscd on whether likely future deficits imply levels of Federal debt that are consistent with monetary stability.

How a current deficit might affect anticipations of future monetary and fiscal policy is thus a key issue. 


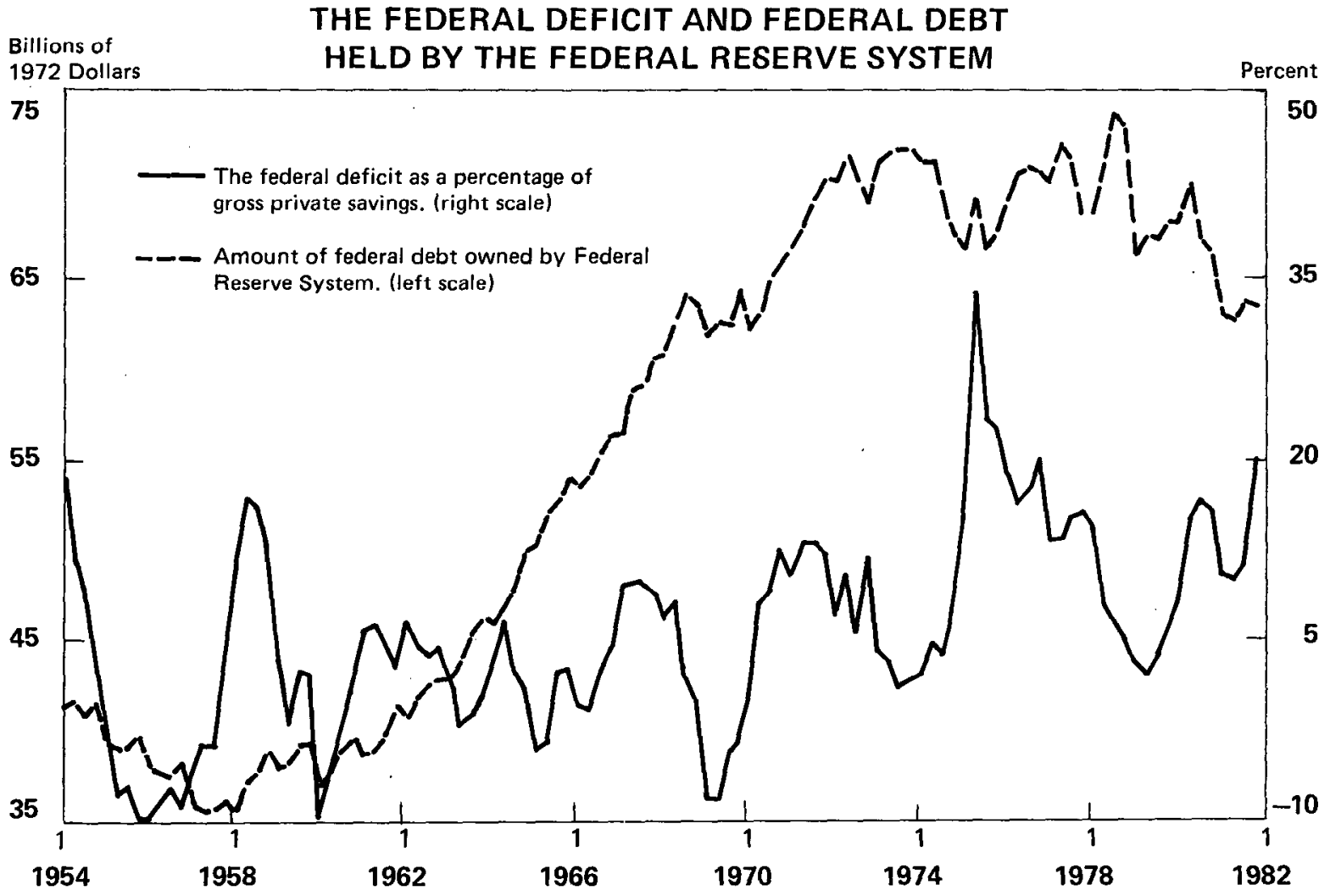

If: the Federal Reserve were to monetize Federal deficits, then the Fed's holdings of government debt would rise sharply when deficits increased. It is difficult, however, to see evidence of such behavior in this graph.

Most analyses based on the IS-LM framework, whether as simple as the model employed above or as complex as the major econometric models, evade the question of policy anticipations. But modeling the formation and evolution of policy anticipations has proved difficult, except for strongly restricted special cases. One small step is to include policy anticipations in the conventional model by letting current private bond demand be affected by the perceived risk of future inflationary policy. Thus a policy that would invalidate current anticipations (such as the unanticipated deficit introduced above) could (1) increase the perceived likelihood of a policy fostering higher inflation in the future, thereby (2) lowering current net private bond demand, and consequently (3) raising the current interest rate more than predicted by the simple model.

\section{Back-of-the-Envelope Estimation}

In the appendix, the responsiveness of interest rates to a one-time change in the nominal value of government debt is shown (at least, within the simple
IS-LM model that ignores policy anticipations) to depend upon the responsiveness of individuals' (both domestic and foreign) net demand for bonds with respect to the interest rate and the interest response of money demand. The specific expression is given by equation 6 . An interesting exercise is to use that equation to calculate a rough estimate for the change in interest rates resulting from a change in the Federal debt. Under the assumption that net bond demand is somewhat responsive to interest rates while money demand is slightly responsive, ${ }^{4}$ a 1 percent change in the stock of Federal debt would only result in a 1 percent change in the interest rate. In order to get an idea of the magnitudes involved,

\footnotetext{
4 More precisely, let the interest elasticity of net bond demand be equal to 0.95 , and the interest elasticity of money demand be equal to -0.05 . The latter is consistent with many econometric estimates. The interest elasticity of net bond demand is not often estimated; however. Since U. S. government debt, corporate debt, and foreign debt are close substitutes, a substantial interest elasticity of net bond demand appears reasonable. The exact parameter value is uncertain, however, and others may not agree as to what is reasonable.
} 
consider a $\$ 100$ billion government deficit when the stock of Federal debt is $\$ 1$ trillion, and the interest rate is 15 percent (the numbers approximate recent values). If the deficit were reduced to zero, the upper limit would imply only a 150 basis point decline in the interest rate. These calculations are only illustrative, however, in that they ignore any effect of changed anticipations of future policy and, in addition, abstract from measurement problems connected with the Federal debt.

\section{Conclusion}

Interest rates serve the purpose of equating the supply of lending and the demand for borrowing. Federal borrowing demands, although important, are only a single element in the supply-demand framework. Thus it is easy to overstate the responsiveness of interest rates to the current Federal deficit by failing to consider demands for and supplies of credit by individuals, firms, and foreign governments. Even if the importance of the current deficit is often overstated, however, it could be important to consider the effects of current deficits on individuals' anticipations of future fiscal and monetary policies.

Accordingly, while simply reducing the current level of the deficit would probably not lower interest rates substantially, important policy considerations remain. For one, fiscal actions can affect incentives for private sector borrowing and lending; thus a policy designed to lower credit demand and increase supply could lower interest rates. Recently discussed examples include limiting the tax deductibility of interest paid, expanding opportunities to receive taxfree interest, and reducing Federal subsidies for borrowing.

It is appropriate at this point to consider anticipations of future policy actions. A major concern is that current and prospective fiscal actions will lead to a monetary acceleration in the future. And to the extent that individuals' anticipations of future mones tary policy include some likelihood that high and variable rates of inflation will be fostered, the supply of long-term credit will be restricted. Reducing that likelihood in private anticipations could be accomplished by a monetary rule-that is, an economic strategy to achieve low inflation that is publicly announced (in full detail), well understood by the general public, credible, verifiable, and perceived as being difficult for policymakers to change or circumvent regardless of fiscal actions. Such a rule would break any link between current deficits and anticipations of future monetary growth and, thereby, could reduce any risk premium in current interest rates that reflects the probabliity of future inflation. Since monetary actions do not currently conform to the requirements for a monetary rule listed above, it should be emphasized that the design and implementation of such a rule would not be a trivial task. However, it is difficult to see any quicker way to restore a high degree of confidence in future monetary actions.

\section{References}

1. Barro, Robert. "Are Government Bonds Net Wealth?" Joumal of Political Economy (November/December 1974).

2. Blinder, Alan, and Robert Solow. "Analytical Foundations of Fiscal Policy," in The Economics of Public F'inance. Washington: Brookings Institution, 1974.

3. Council of Economic Advisers. Annual Report. Washington: Government Printing Office, 1982.

4. McCallum, Bennett T. "Are Bond-Financed Deficits Inflationary?" Unpublished manuscript. May 1982.

5. "McGillicuddy: Deficits Do Matter." American Banker, March 11, 1982.

6. Mundell, Robert. "Capital Mobility and Stabilization Policy under Fixed and Flexible Exchange Rates." Canadian Journal of Economics and Political Science (November 1963).

7. Patinkin, Don. Money, Interest, and Prices. 2nd ed. New York: Harper and Row, 1965.

8. "Thrift Industry Urges Cut in U. S. Deficit." The Wall Street Journal, March 4, 1982.

9. Young, Alan, and John Musgrave. "Estimation of Capital Stock in the United States," in Dan Usher, ed., The Measurement of Capital. Chicago: University of Chicago Press, 1980. 


\begin{abstract}
The purpose of this appendix is to derive the elasticity of the interest rate with respect to government bond issue. There are three markets: commodity, money, and bonds. When supply equals demand in the money and bond markets, we know by Walras' Law that the commodity market clears. Market clearing in the money market is represented by

$$
\text { (1) } \frac{\mathrm{M}}{\mathrm{P}}=\mathrm{L}(\mathrm{Y}, \mathrm{R})
$$
\end{abstract}

where $\mathrm{M}$ is the quantity of money (fixed by the monetary authority), $\mathrm{P}$ is the commodity price level, $\mathrm{L}$ is the demand for real money balances, $\mathrm{Y}$ is the level of real output, and $\mathrm{R}$ is the bond interest rate.

The real quantity of government bonds is represented as $\frac{B}{R P}$, where $B$ is the number of government bonds (a bond is a credible promise to pay $\$ 1$ per year forever), $R$ is the rate of interest (consequently $\frac{1}{R}$ is the nominal price of a bond), and thus $\frac{B}{R}$ is the nominal market value of government bonds.

Real net demand for bonds, $Z$, is defined as

$$
\text { (2) } \mathrm{Z}(\mathrm{Y}, \mathrm{R}) \equiv \mathrm{H}(\mathrm{Y}, \mathrm{R})-\mathrm{J}(\mathrm{Y}, \mathrm{R})
$$

where $\mathrm{H}$ is the private real demand for bands and $J$ is the private real supply of bonds (the private sector will include foreign individuals if an integrated world bond market is assumed). Since $H_{R}\left(=\frac{\partial H}{\partial R}\right)$ is positive and $J_{R}$ is negative, $Z_{R}$ is unambiguously positive. Market clearing is represented as
(3) $\frac{\mathrm{B}}{\mathrm{RP}}=\mathrm{Z}(\mathrm{Y}, \mathrm{R})$.

To look at growth rates, take logs of (1) and (3) and differentiate, holding $M$ and $Y$ (at its fullemployment level) constant. Small letters will represent growth rates (i.e., $m=\frac{d M}{M}$ ), and $\epsilon_{1, J}$ is the elasticity of $I$ with respect to $J$.

From (1),

$$
\begin{gathered}
-\mathrm{p}=\frac{1}{\mathrm{~L}} \mathrm{~L}_{\mathrm{R}} \mathrm{dR} \\
\text { or (note } \left.\frac{1}{\mathrm{~L}} \mathrm{~L}_{\mathrm{R}} \mathrm{dR}=\left(\frac{\mathrm{R}}{\mathrm{T}} \mathrm{L}_{\mathrm{R}}\right) \frac{\mathrm{dR}}{\mathrm{R}}\right) \\
\text { (4) } \mathrm{p}=-\epsilon_{\mathrm{L}, \mathrm{R}} \mathrm{r} .
\end{gathered}
$$

From (3),

$$
\mathrm{b}-\mathrm{r}-\mathrm{p}=\frac{1}{\mathrm{Z}} \mathrm{Z}_{\mathrm{R}} \mathrm{dR} \quad \text { or }
$$

(5) $\mathrm{p}=\mathrm{b}-\left(1+\epsilon_{\mathrm{Z}, \mathrm{R}}\right) \mathrm{r}$.

Combining (4) and (5) yields

$$
-\epsilon_{\mathrm{L}, \mathrm{R}} \mathrm{r}=\mathrm{b}-\left(1+\epsilon_{\mathrm{Z}, \mathrm{R}}\right) \mathrm{r}
$$

and therefore,

(6) $\epsilon_{\mathrm{R}, \mathrm{B} / \mathrm{R}} \equiv \frac{\mathrm{r}}{\mathrm{b}-\mathrm{r}}=\frac{1}{\epsilon_{\mathrm{Z}, \mathrm{R}}-\epsilon_{\mathrm{L}, \mathrm{R}}}$.

Since this model does not include continuing inflation, there is no distinction between nominal and real interest rates. 